\title{
Experiment on RC Beams Reinforced with Glass Fibre Reinforced Polymer Reinforcements
}

\author{
R.Murugan, G.Kumaran
}

\begin{abstract}
This study presents the flexural behaviour of rectangular concrete beams reinforced with surface treated Glass Fibre Reinforced Polymer (GFRP), Grooved bars and Sand sprinkled reinforcing bars. Beams cast with standard mix of M30 grade concrete, with a reinforcement ratios of $0.73 \%$, and compared with that of conventional steel reinforced beams. Totally five rectangular beams of size $125 \mathrm{~mm} \times 250 \mathrm{~mm} \times 3200$ mm were cast. The flexural study was carried under static two point loading. The experimental prediction was focused on observation of ultimate load capacity, cracks propagation and crack widths and failure modes of beams. The results indicate that both type of GFRP reinforcements are at par with the conventional steel reinforcements.
\end{abstract}

Key words:-Rectangular beams; GFRP; Reinforcement ratio; Ultimate load; Flexural strength

\section{INTRODUCTION}

In coastal areas, most of the buildings are being affected by corrosion of reinforcements. The rate of corrosions depends on exposure condition of buildings and cover to the reinforcements. The conventional material used for reinforcements is made of steel. But, steel cannot withstand the aggressive environment condition. Hence, an alternate reinforcement is found from the promotion of fibre reinforced polymer (FRP) rods. The use of FRP rods are giving promising solution to corrosion of steel reinforcement in structure. Now a days, FRP bars are available in glass, carbon and aramid fibres and as hybrid rods with the combination of fibres. This experimental study, glass fibre reinforcement rods are used in beams.

The main issue of using FRP bars is bond between rod and concrete. To develop a better bond resistance, two types of FRP bars are used. ie. Sand coated and grooved bars. FRP bars possess low weight to strength ratio, relatively low elastic modulus, high dimensional stability and easy handling and transportation determines the use of FRP in $\mathrm{RC}$ structures. The performance of these FRP reinforced bar in $\mathrm{RC}$ beams is evaluated and presented.

\section{LITERATURE REVIEW}

Dinesh Kumar and Sathish Kumar (2018) [1] compared the experimental and analytical findings on the centrally loaded beams reinforced with GFRP rods and steel bars along with GFRP stirrups, and concluded that the GFRP

Revised Manuscript Received on April 12, 2019.

Dr.R.Murugan,Assistant Professor, Department of Civil \& Structural Engineering, Annamalai University, Annamalainagar - 608002, Tamilnadu, India. (ermurugan.cdm@gmail.com)

G.Kumaran, Professor, Department of Civil \& Structural Engineering, Annamalai University, Annamalainagar - 608002, Tamilnadu, India. rods reinforced beam exhibits more ductility than steel bar reinforced beams.

Saraswathy and Dhanalakshmi (2014) [2] performed the experiment on GFRP reinforced RC beams, and evaluated the parameters influencing the flexural failure modes, width of cracks, ultimate load capacity, load versus deflection and flexibility of concrete beams.

KhaledGalal and Munir Alp Enginsal (2011) [3] studied the experimental behaviour of masonry beams internally reinforced with GFRP bars. The experimental findings of flexural capacity, deformation and curvature are correlated with the analytical solution and effectiveness of GFRP bars are listed.

Ascioneet al. (2010) [4] evaluated the static behaviour under service condition of concrete beams reinforced with GFRP and CFRP bars, with two grades of concrete with two reinforcement ratio. The midspan deflection, crack width and behaviour up to failure are investigated, and the salient results are listed and discussed.

\section{EXPERIMENTAL INVESTIGATIONS}

The experimental program involves two parts. In the first part, the material properties are obtained and in second part, testing of five numbers of full scale beams of size $125 \mathrm{~mm} x$ $250 \mathrm{~mm}$ x $3200 \mathrm{~mm}$ carried out by performing two point static load test, on all the casted beams after 28 days curing. Two types of surface treated GFRP rods (Sand coated and Grooved) and conventional steel rod are used. The mix proportion of standard mix M30was designed as per IS 10262:2009[5] and as per IS 456:2000[6]. Two reinforcement ratios of $0.73 \%$ and $1.08 \%$ were used. The tensile test on steel are tested as per IS 1608-2005[7]. The tensile test on GFRP rods were performed as per ASTM standard ASTM-D 3916-1984[8]s, as bureau of Indian standard is not available for GFRP rods testing

\subsection{Cement}

Ordinary Portland Cement (OPC) 53 grade satisfying IS 12269:1987[9] was used. The properties of the cement are given in Table 1.

Table 1 Properties of Cement

\begin{tabular}{|c|c|}
\hline Description & Property \\
\hline Colour & Grey \\
\hline Specific gravity & 3.15 \\
\hline Standard consistency & $30 \%$ \\
\hline
\end{tabular}




\begin{tabular}{|c|c|}
\hline Initial setting time & 34 minutes \\
\hline Final setting time & 176 minutes \\
\hline
\end{tabular}

\subsection{Fine Aggregate}

Locally available river sand confirming IS 2386 (Part III): $1963[10]$ was used. The properties of fine aggregate is given in Table 2.

Table 2 Properties of Fine Aggregate

\begin{tabular}{|c|c|}
\hline Description & Property \\
\hline Size & $2.75 \mathrm{~mm}$ \\
\hline Specific gravity & 2.61 \\
\hline Fineness modulus & 3.24 \\
\hline
\end{tabular}

\subsection{Coarse Aggregate}

The coarse aggregate of size $20 \mathrm{~mm}$ confirming to IS 2386 (Part III): 1963[10] were used. The properties of coarse aggregate is given in Table 3 .

Table 3 Properties of Coarse Aggregate

\begin{tabular}{|c|c|}
\hline Description & Property \\
\hline Size & $20 \mathrm{~mm}$ \\
\hline Specific gravity & 2.73 \\
\hline Water absorption & $1.20 \%$ \\
\hline Bulk density & $1752 \mathrm{~m}^{3}$ \\
\hline
\end{tabular}

\subsection{Water}

Normal potable water was used for mixing and curing.

\subsection{Admixture}

Super plasticizer, Conplast SP337 conforms to IS: 9103: 1999[11] used as a water reducing admixture. Table 4 shows the physical properties of super plasticizer.

Table 4 Physical properties of Superplasticizer

\begin{tabular}{|c|c|}
\hline Properties & Values /Indication \\
\hline Colour & Brown \\
\hline Odour & Slight/faint \\
\hline Specific gravity & 1.18 to 1.20 at $27^{\circ} \mathrm{C}$ \\
\hline Chloride ion content & Nil \\
\hline $\mathrm{pH}$ & $7-8$ \\
\hline Relative Density & 1.17 to 1.19 at $20^{\circ} \mathrm{C}$ \\
\hline
\end{tabular}

\subsection{Reinforcements}

Steel rod of Fe415 grade, sand coated and grooved GFRP rods are tested in the Universal Testing Machine (UTM) of capacity $1000 \mathrm{kN}$. The GFRP rods are shown in figures 1(a) and 1(b). the gripping setup of GFRP rods for tensile test as per ASTM standards are shown in figures 2(a) and 2(b). The tensile test of GFRP rods are shown in figures3(a) and 3(b). The properties of the reinforcements are given in Table 5 .

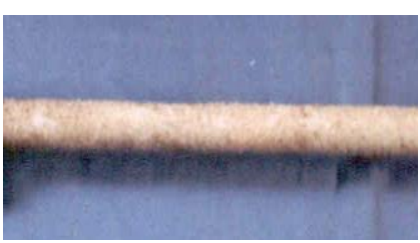

Figure 1(a) Sand Coated GFRP

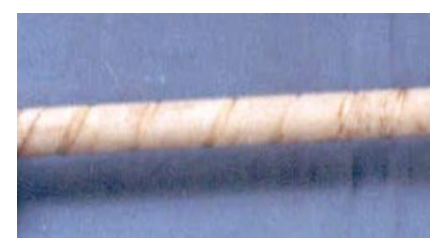

Figure 1(b) Grooved GFRP
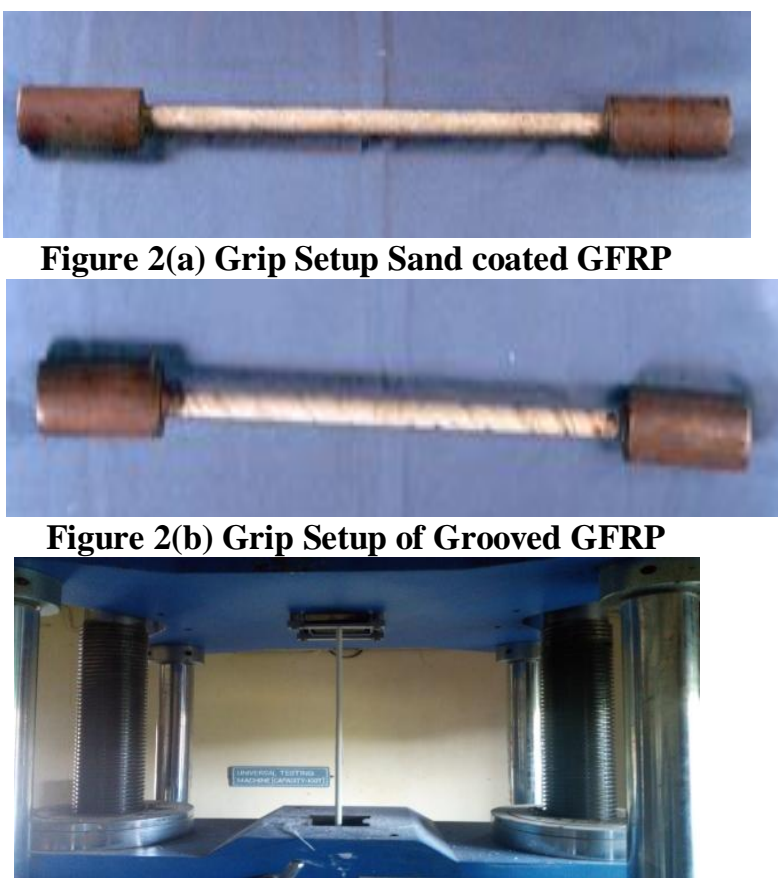

Figure 3(a) Tensile Testing of GFRP

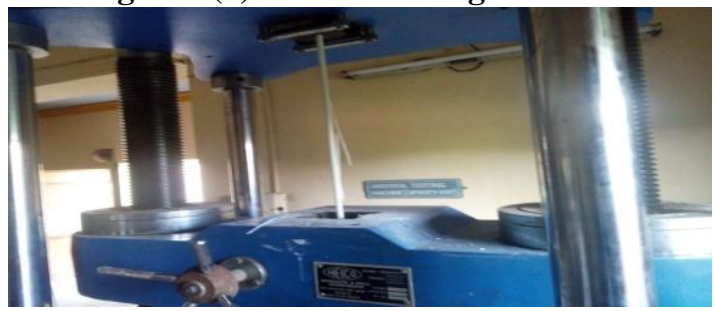

Figure 3(b) Failure of GFRP

Table 5 Properties of Reinforcements

\begin{tabular}{|c|c|c|c|}
\hline \multirow{2}{*}{ Description } & \multicolumn{3}{|c|}{ Value } \\
\cline { 2 - 4 } & Steel $\left(\mathbf{F}_{\boldsymbol{e}}\right)$ & $\begin{array}{c}\text { Sand } \\
\text { Coated } \\
\text { GFRP }\left(\mathbf{F}_{S}\right)\end{array}$ & $\begin{array}{c}\text { Grooved } \\
\text { GFRP }\left(\mathbf{F}_{g}\right)\end{array}$ \\
\hline $\begin{array}{c}\text { Yield Strength } \\
(\mathrm{MPa})\end{array}$ & 560 & 690 & 625 \\
\hline $\begin{array}{c}\text { Longitudinal } \\
\text { Elastic Modulus } \\
(\mathrm{GPa})\end{array}$ & 218 & 69.0 & 61.0 \\
\hline Strain & 0.0014 & 0.029 & 0.031 \\
\hline Poisson's Ratio & 0.26 & 0.221 & 0.215 \\
\hline
\end{tabular}

\section{CONCRETE}

\subsection{Mix Proportions}

Mix design of concrete was performed as per IS 10262: 2009[5] and IS 456: 2000 [6]. Standard mix of M30 grade was adopted in this study. The details of mix proportions are given in Table $6 . \mathrm{s}$

\section{Published By:}

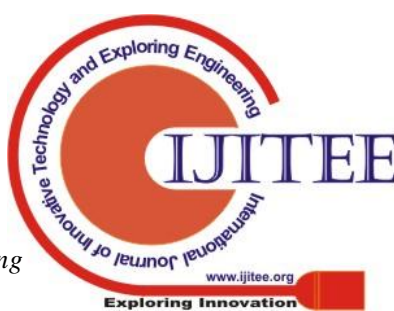


Table 6 Concrete Mix Proportions

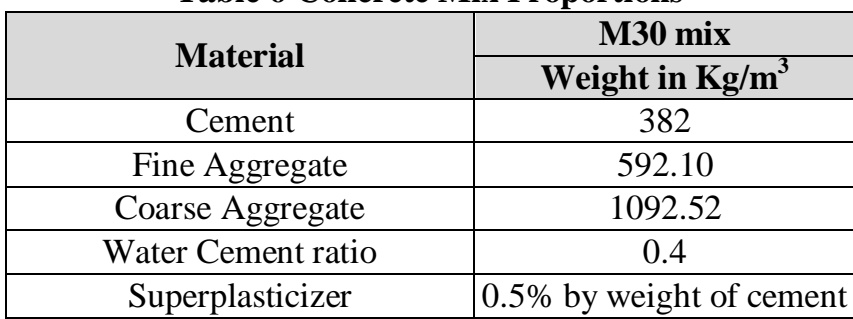

\subsection{Hardened Concrete}

The compressive strength of cube and cylinder were found after 28 days of normal water curing. $150 \mathrm{~mm}$ cubes and $150 \mathrm{~mm}$ dia and $300 \mathrm{~mm}$ height cylinder specimens were tested as per IS 516: 1959[12]. The compressive strength values of two mix proportions are shown in Table 7.

Table 7 Compressive Strength of Hardened Concrete

\begin{tabular}{|c|c|}
\hline Description & Compressive Strength (MPa) \\
\hline M20 mix & 26.81 \\
\hline M30 mix & 31.42 \\
\hline
\end{tabular}

\section{EST SPECIMENS}

Five full scale beams were cast with same dimensions of $125 \mathrm{~mm}$ x $250 \mathrm{~mm}$ x 3200mm. Two beams were cast with sand coated and two beams were cast with grooved GFRP bars with two reinforcement ratios of $0.73 \%$ and $1.24 \%$. A control beam was cast with conventional steel with $0.73 \%$ reinforcement ratio for comparison of test results with GFRP rods. The details of beams are shown in figures 4 and its dimensions are given in Table 8. The reinforcement details of beams are given in Table 9. The reinforcement cage of steel and GFRP beams are shown in figures 5(a) to 5(c). The details of beam designation are given in Table 10. The steel rod are tied with stirrups using mild steel wires, whereas the GFRP rods are tied with GFRP stirrups with nylon zip ties, in order to achieve cent percent corrosion free cage.

Table 8 Beam Dimensions

\begin{tabular}{|c|c|}
\hline Description & $\begin{array}{c}\text { Dimension } \\
\text { (mm) }\end{array}$ \\
\hline Breadth (b) & 125 \\
\hline Overall Depth (D) & 250 \\
\hline Effective Depth (d) & 219 \\
\hline
\end{tabular}

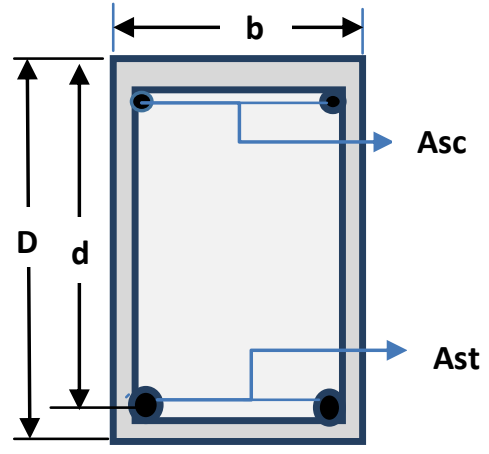

Figure 4 Beam Details

Table 9 Reinforcement Details of Beams

\begin{tabular}{|c|c|c|c|}
\hline $\begin{array}{c}\text { Reinforcement } \\
\text { Ratio }(\boldsymbol{\rho})\end{array}$ & Tension & Compression & $\begin{array}{c}\text { Shear } \\
\text { Stirrups }\end{array}$ \\
\hline $0.73\left(\boldsymbol{\rho}_{\mathbf{1}}\right)$ & $2-12 \mathrm{Y}$ & $2-10 \mathrm{Y}$ & $\begin{array}{c}8 \mathrm{Y}-150 \mathrm{~mm} \\
\mathrm{c} / \mathrm{c}\end{array}$ \\
\hline $1.08\left(\boldsymbol{\rho}_{\mathbf{2}}\right)$ & $3-12 \mathrm{Y}$ & $2-10 \mathrm{Y}$ & $\begin{array}{c}8 \mathrm{Y}-150 \mathrm{~mm} \\
\mathrm{c} / \mathrm{c}\end{array}$ \\
\hline
\end{tabular}

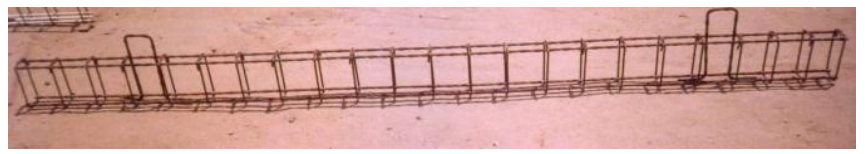

Figure 5(a) Steel Reinforcement Cage

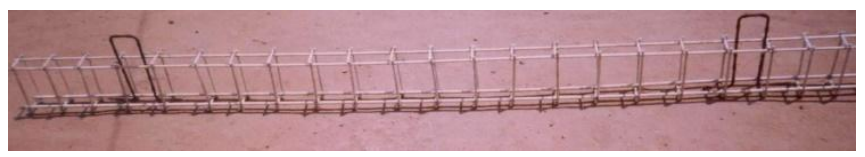

Figure 5(a) Steel Reinforcement Cage

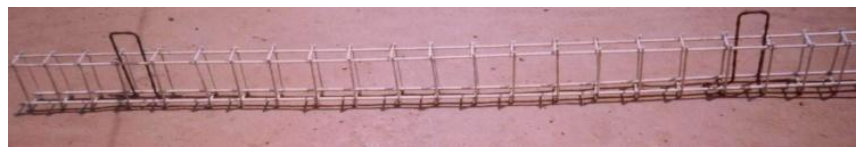

Figure 5(b) Sand Coated GFRP Reinforcement Cage

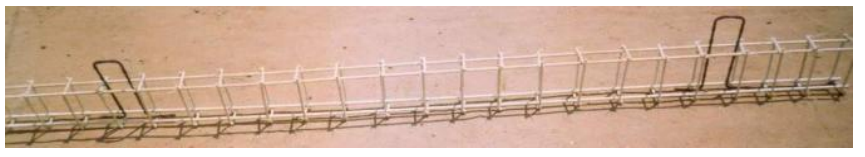

Figure 5(c) Grooved GFRP Reinforcement Cage

Table 10 Designation of Beams

\begin{tabular}{|c|c|c|c|c|}
\hline $\begin{array}{c}\text { Sl. } \\
\text { No. }\end{array}$ & $\begin{array}{c}\text { Beam } \\
\text { Designation }\end{array}$ & $\begin{array}{c}\text { Concrete } \\
\text { Mix }\end{array}$ & $\begin{array}{c}\text { Type of } \\
\text { Reinforcement }\end{array}$ & $\begin{array}{c}\text { Reinforcement } \\
\text { Ratio }\end{array}$ \\
\hline 1 & $B m_{1} F_{e} \rho_{1}$ & $\mathrm{M} 30$ & Steel & 0.73 \\
\hline 2 & $B m_{1} F_{S} \rho_{1}$ & $\mathrm{M} 30$ & $\begin{array}{c}\text { Sand coated } \\
\text { GFRP }\end{array}$ & 0.73 \\
\hline 3 & $B m_{1} F_{S} \rho_{2}$ & $\mathrm{M} 30$ & $\begin{array}{c}\text { Sand coated } \\
\text { GFRP }\end{array}$ & 1.08 \\
\hline 4 & $B m_{1} F_{g} \rho_{1}$ & $\mathrm{M} 30$ & $\begin{array}{c}\text { Threaded } \\
\text { GFRP }\end{array}$ & 0.73 \\
\hline 5 & $B m_{1} F_{g} \rho_{2}$ & $\mathrm{M} 30$ & $\begin{array}{c}\text { Threaded } \\
\text { GFRP }\end{array}$ & 1.08 \\
\hline
\end{tabular}

\section{TEST SETUP AND INSTRUMENTATION}

All the beams are tested under monotonically increasing static two point loading condition. The beams are kept on simple support system i.e. one end of the beam rests on hinge support and the other end rests on roller support. The horizontal line is maintained by checking support end levels of the beams by spirit levels. The routine deformation measuring gauges such as dial gauges, strain gauges (with strain rosettes), LVDTs, Demec gauges are utilized to capture the responses.

All beams have internally glued strain gauges. Internally glued strain gauges are placed on the surface of the

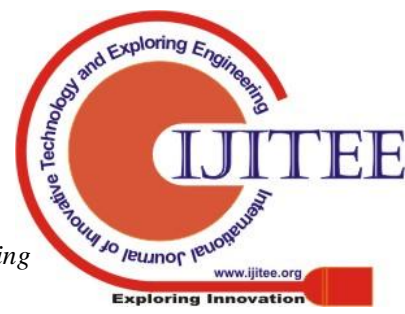


steel/GFRP reinforcements before it is being cast. Dial gauges are also fixed at centre, one-third load points and at supports. Demec gauges are also pasted in flanges and in the web portions at centre and at one-third load points to measure the linear strains. Linear variable Displacement Transducers (LVDT- range0-100mm) are used to measure vertical deflections at one-third load points. The load increment for static loading is kept at the rate of $2 \mathrm{kN} / \mathrm{sec}$ and it is maintained up to failure. The crack widths microscopes are utilized to monitor the crack growth periodically. The entire static loading schematic testing set up is illustrated in Figure 6.

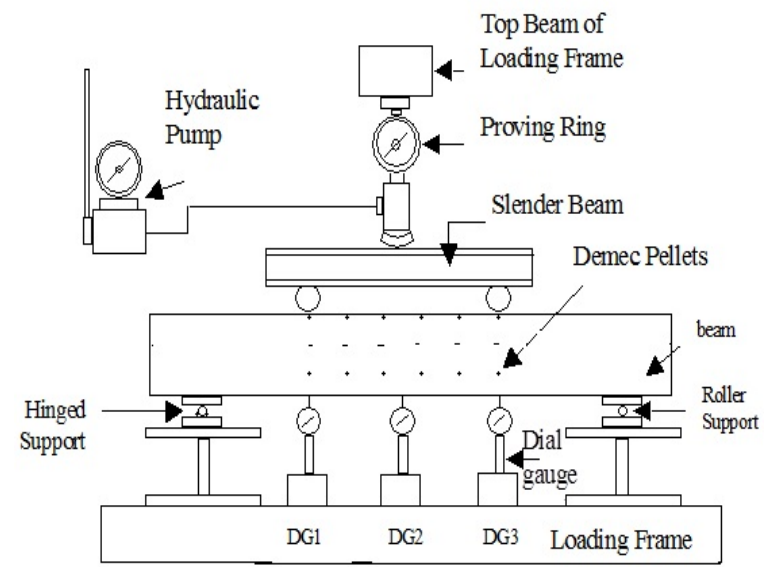

Figure 6 Schematic Illustration of Test Setup

\section{EXPERIMENTAL RESULTS AND DISCUSSION}

The experimental results are given in Table 11. The load versus deflection of all beams is shown in figure 7 . The moment versus curvature of all beams are shown in figure 8 . The stress versus strain values observed at the concrete interface from the strain gauge glued at the centre of reinforcement is shown in figure 9. The failure patterns of all beams are shown in figure 10 to 14 . The observed crack patterns of all the beams are shown in figures 15 to 34 .

\subsection{Load versus Deflection}

The ultimate load of steel reinforced beam $B m_{1} F_{e} \rho_{1}$ is 40 $\mathrm{kN}$, the sand coated and grooved rod reinforced beams $B m_{1} F_{S} \rho_{1}$ and $B m_{1} F_{g} \rho_{1}$ are $34 \mathrm{KN}$ and $38 \mathrm{kN}$ respectively, which is $15 \%$ and $5 \%$ less when compared with steel reinforced beam . At the same time when the reinforcement ratio of GFRP beams increased to $1.08 \%$, the ultimate load increased to $50 \mathrm{KN}$ and $56 \mathrm{kN}$, which is $25 \%$ and $40 \%$ in sand coated and grooved rod reinforced beams. The ultimate load of beam increases with increase in percentage of reinforcement in GFRP reinforced beams. The ultimate deflection of grooved rod beams is less when compared to sand coated rod beams when increasing the reinforcement ratio.

\subsection{Moment versus Curvature}

The moment-curvature relation of a section is characterized according to the dimensions of the concrete section and the material properties of concrete and steel. Also, the gradient of the moment-curvature relation means the elastic bending stiffness EI which includes all the section properties in a typical loading condition. All the five beams tested under static loading procedure are observed for their moment curvature behaviour. The profile of ultimate load reflects in moment capacity at failure

Table 11 Experimental Results

\begin{tabular}{|c|c|c|c|c|c|}
\hline \multirow[b]{2}{*}{$\begin{array}{c}\text { Designation } \\
\text { of Beams }\end{array}$} & \multicolumn{5}{|c|}{ Experimental Values } \\
\hline & \begin{tabular}{|l|} 
Ult \\
Load \\
$(k N)$
\end{tabular} & $\begin{array}{l}\text { Deflection } \\
(\mathbf{m m})\end{array}$ & $\begin{array}{c}\text { Moment } \\
(\mathrm{kN}-\mathrm{m})\end{array}$ & $\begin{array}{l}\text { Curvature } \\
\left(\times 10^{-3}\right. \\
\text { Radians })\end{array}$ & $\begin{array}{l}\text { Crack } \\
\text { width } \\
\text { (mm) }\end{array}$ \\
\hline$B m_{1} F_{e} \rho_{1}$ & 40 & 28.40 & 20 & 2.52 & 0.52 \\
\hline$B m_{1} F_{S} \rho_{1}$ & 34 & 34.80 & 17 & 4.24 & 0.78 \\
\hline$B m_{1} F_{S} \rho_{2}$ & 50 & 39.62 & 25 & 3.26 & 0.82 \\
\hline$B m_{1} F_{g} \rho_{1}$ & 38 & 41.68 & 19 & 4.21 & 0.84 \\
\hline$B m_{1} F_{g} \rho_{2}$ & 56 & 36.85 & 28 & 3.18 & 0.90 \\
\hline
\end{tabular}

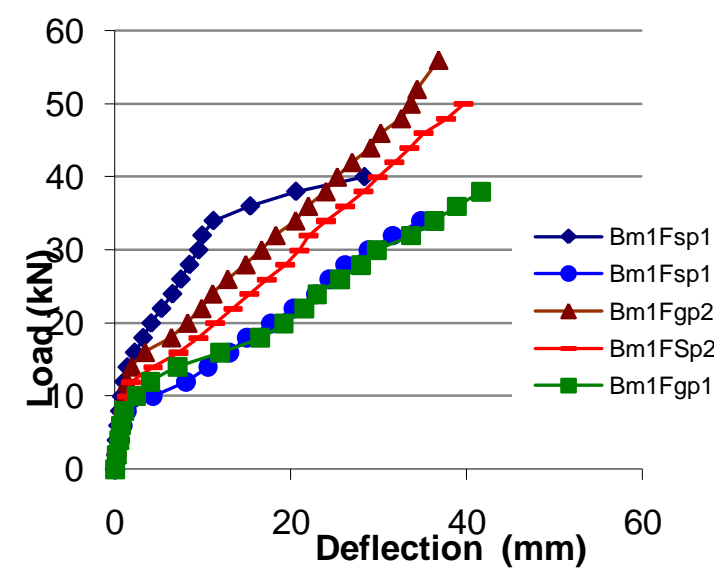

Figure7LoadversusDeflectionofBeams 7

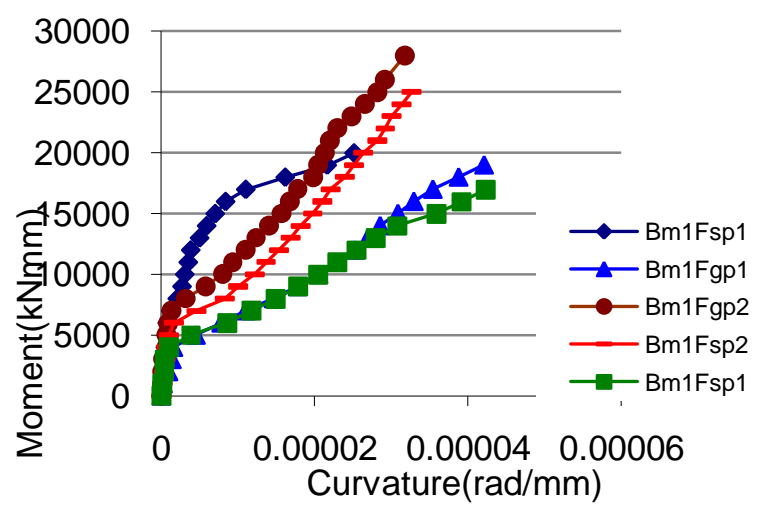

Figure 8 Moment versus Curvature of Beams

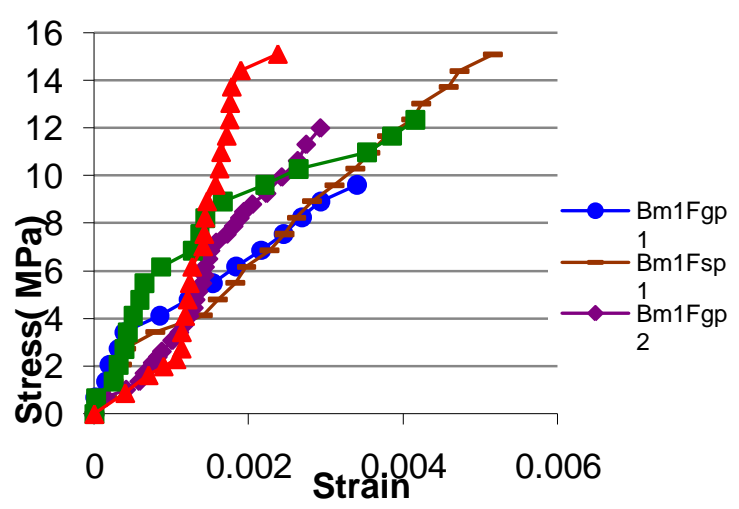

Figure 9 Stress versus Strain of Reinforcements at Concrete Interface

Published By: 


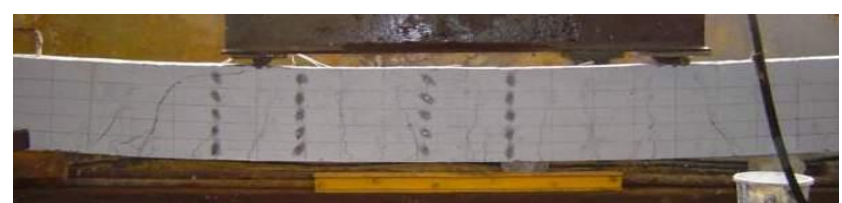

Figure 10 Failure Pattern of $\mathrm{Bm}_{1} \mathrm{~F}_{e} \rho_{1}$

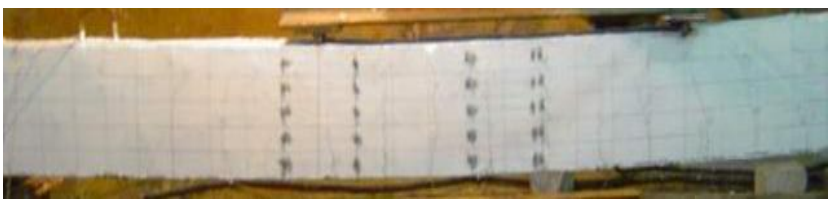

Figure 11 Failure Pattern of $\mathrm{Bm}_{1} F_{s} \rho_{1}$

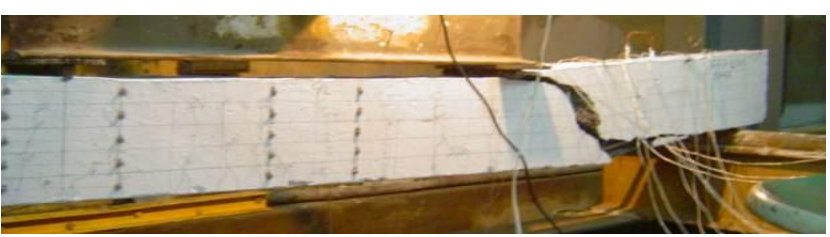

Figure 12 Failure Pattern of $\mathrm{Bm}_{1} \mathrm{Fs}_{2}$

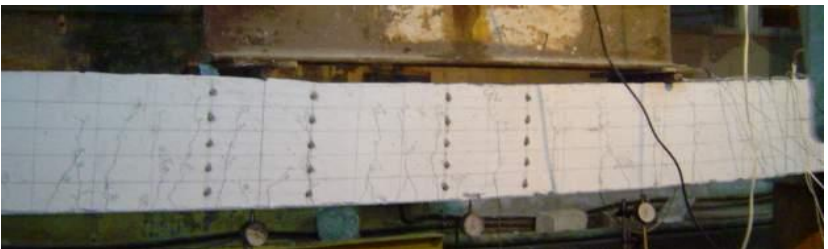

Figure 13 Failure Pattern of $\mathrm{Bm}_{1} F_{g} \rho_{I}$

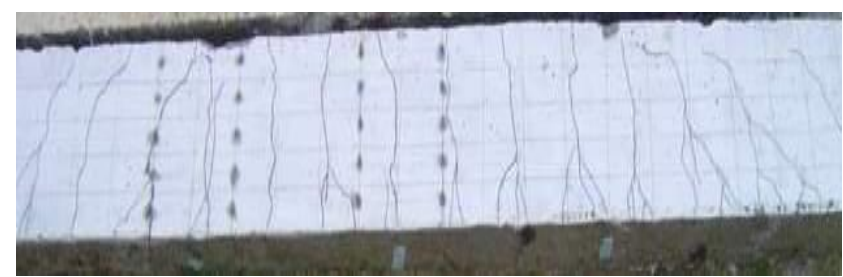

Figure 14 Failure Pattern of $\mathrm{Bm}_{1} \mathrm{~F}_{g} \rho_{2}$

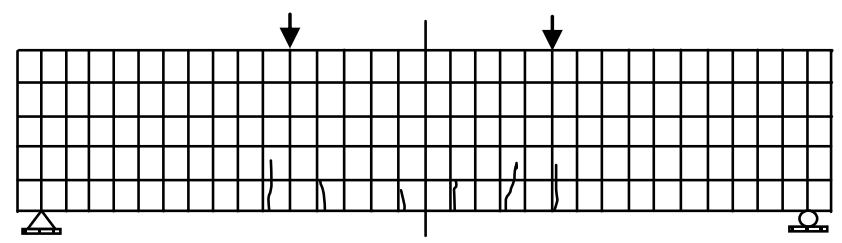

Figure 15 Crack Patternsof Beam $B m_{1} F_{s} \rho_{1}$ at $12 \mathrm{kN}$

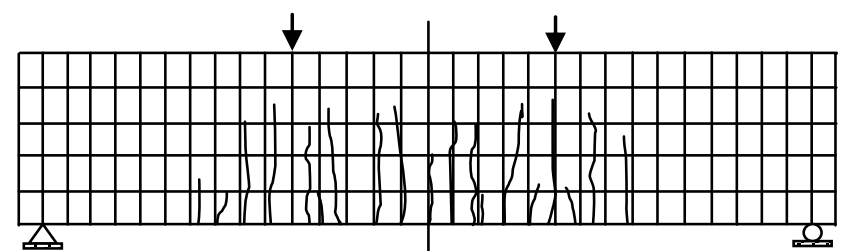

Figure 16 Failure Pattern of $\mathrm{Bm}_{1} F_{e} \rho_{1}$ at $25 \mathrm{KN}$

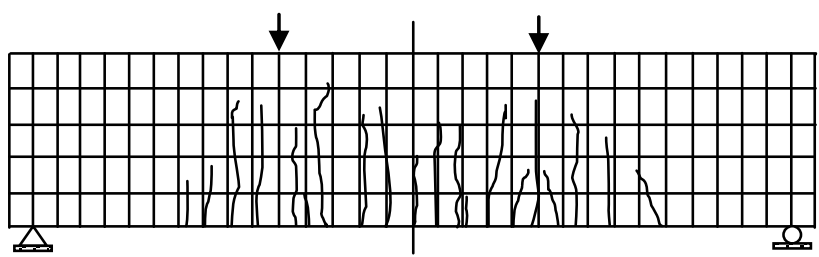

Figure 17 Failure Pattern of $\mathrm{Bm}_{1} F_{e} \rho_{1}$ at $35 \mathrm{kN}$

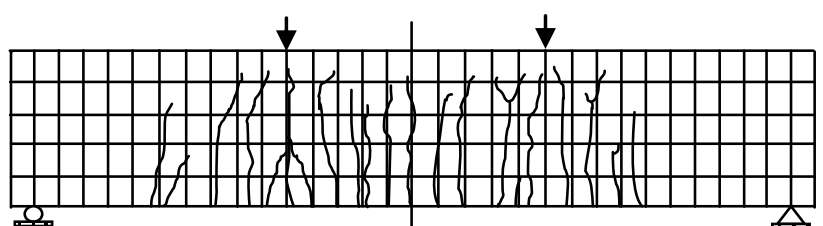

Figure 18 Failure Pattern of $\mathrm{Bm}_{1} F_{e} \rho_{1}$ at $40 \mathrm{kN}$

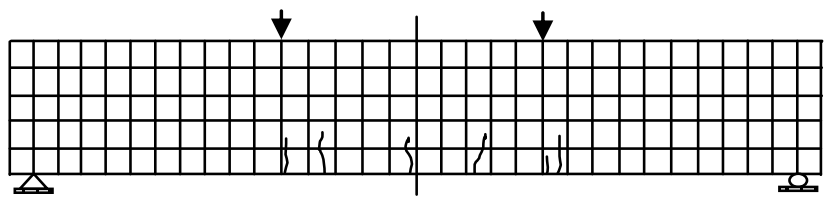

Figure 19 Failure Pattern of $B m_{1} F_{g} \rho_{1}$ at $10 \mathrm{kN}$

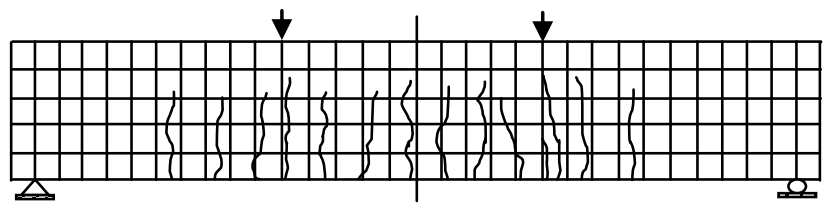

Figure 20 Failure Pattern of $B m_{1} F_{s} \rho_{1}$ at $20 \mathrm{kN}$

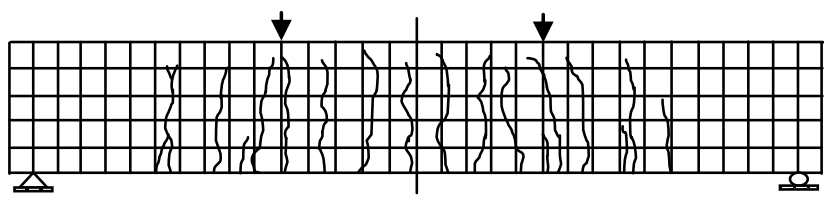

Figure 21 Failure Pattern of $B m_{1} F_{s} \rho_{1}$ at $30 \mathrm{kN}$

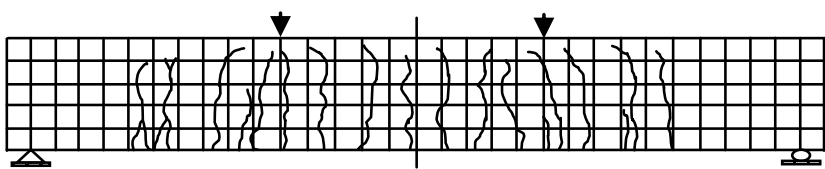

Figure 22 Failure Pattern of $B m_{1} F_{s} \rho_{1}$ at $34 \mathrm{kN}$

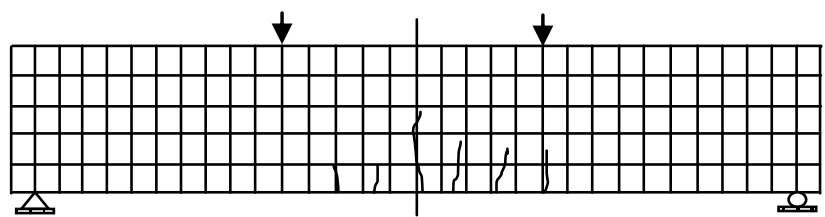

Figure 23 Failure Pattern of $\mathrm{Bm}_{1} F_{g} \rho_{1}$ at $10 \mathrm{kN}$

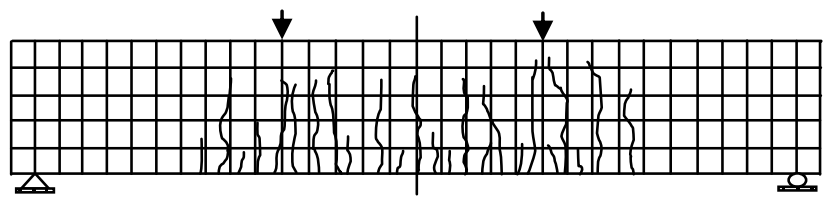

Figure 24 Failure Pattern of $B m_{1} F_{g} \rho_{1}$ at $20 \mathrm{kN}$

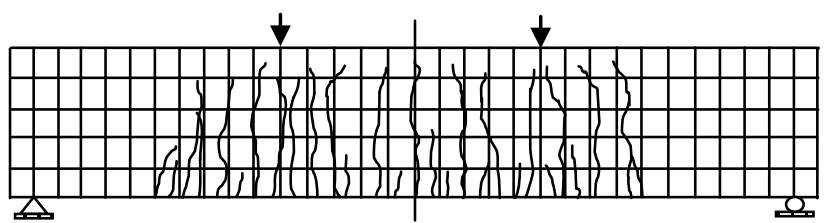

Figure 25 Failure Pattern of $\mathrm{Bm}_{1} F_{g} \rho_{1}$ at $30 \mathrm{kN}$ 


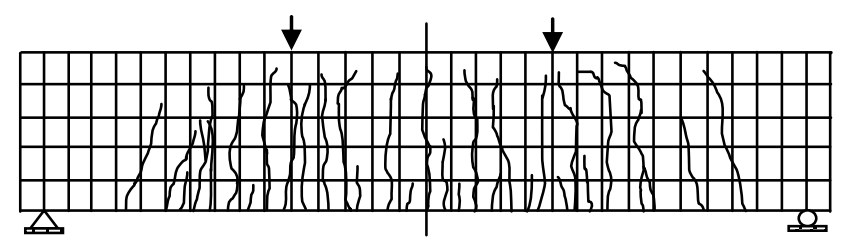

Figure 26 Failure Pattern of $B m_{l} F_{g} \rho_{l}$ at $38 \mathrm{kN}$

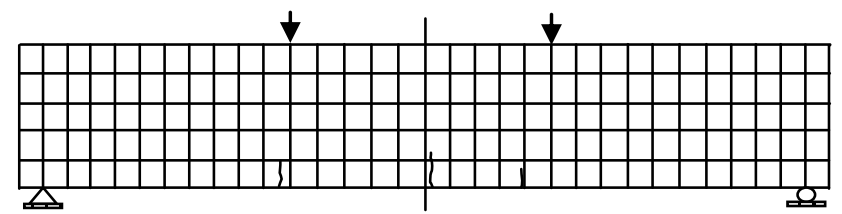

Figure 27 Failure Pattern of $\mathrm{Bm}_{1} F_{s} \rho_{1}$ at $10 \mathrm{kN}$

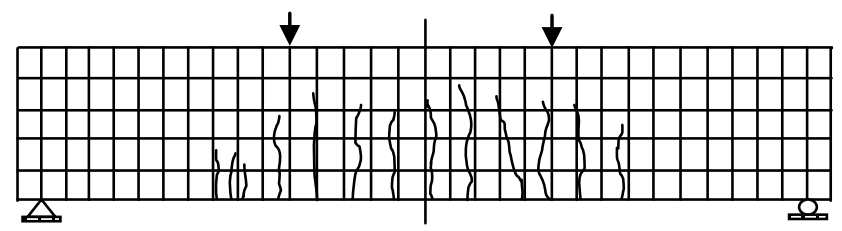

Figure 28 Failure Pattern of $\mathrm{Bm}_{1} F_{s} \rho_{1}$ at $20 \mathrm{kN}$

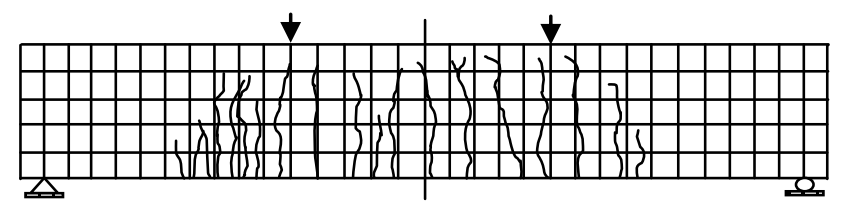

Figure 29 Failure Pattern of $\mathrm{Bm}_{1} F_{s} \rho_{1}$ at $30 \mathrm{kN}$

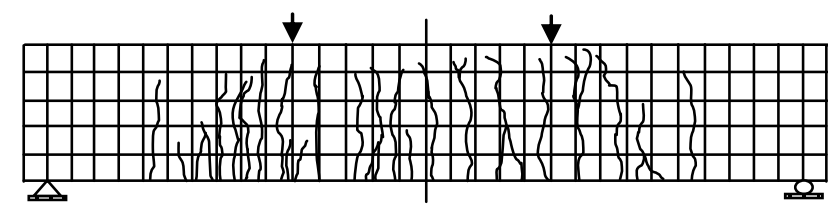

Figure 30 Failure Pattern of $\mathrm{Bm}_{1} F_{s} \rho_{1}$ at $50 \mathrm{kN}$

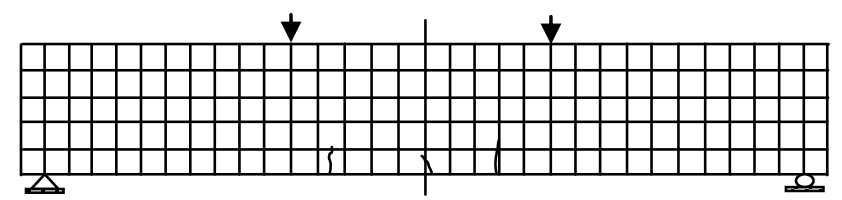

Figure 31 Failure Pattern of $\mathrm{Bm}_{1} F_{g} \rho_{2}$ at $10 \mathrm{kN}$

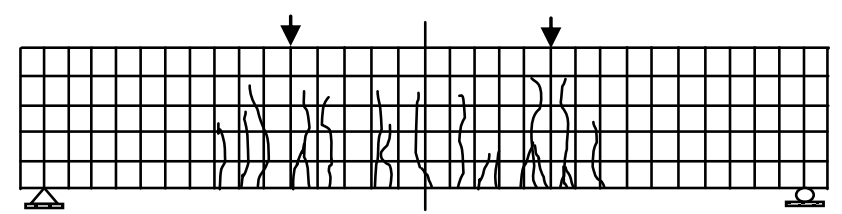

Figure 32 Failure Pattern of $\mathrm{Bm}_{1} F_{g} \rho_{2}$ at $20 \mathrm{kN}$

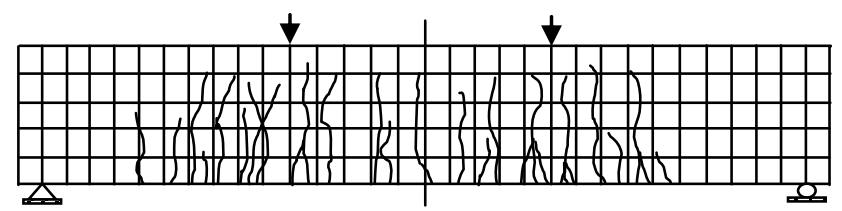

Figure 33 Failure Pattern of $\mathrm{Bm}_{1} F_{g} \rho_{2}$ at $30 \mathrm{kN}$

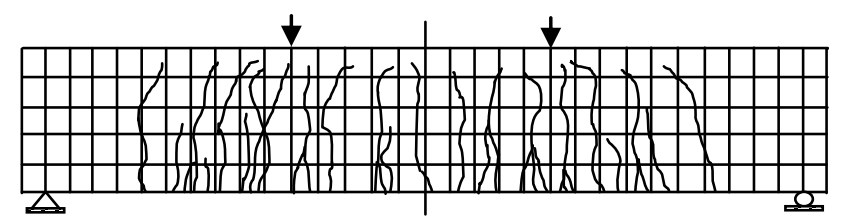

Figure 34 Failure Pattern of $\mathrm{Bm}_{1} F_{g} \rho_{2}$ at $56 \mathrm{kN}$

\section{CONCLUSION}

- The ultimate load carrying capacity of GFRP reinforced beams increases when increase in percentage of reinforcement when compared with steel reinforced beam.

- The ultimate deflection observed in sand coated GFRP reinforced beams show increase in deflection, when increase in percentage of reinforcement. But at the same time, it is reversed in grooved GFRP reinforced beams compared with steel reinforced beams.

- The performance of sand coated GFRP reinforcements is low when compared to grooved GFRP beams with respect to ultimate load carrying capacity and ultimate deflections.

- The ultimate load carrying capacity of sand coated GFRP reinforced beam is $34 \mathrm{kN}$ and $50 \mathrm{kN}$ in $0.73 \%$ and $1.04 \%$ reinforcement ratio and the same in steel reinforced beams is $40 \mathrm{kN}$ in $0.73 \%$ reinforcement ratio. It shows $15 \%$ reduction and $25 \%$ increase in sand coated GFRP reinforced beams compared to conventional steel reinforced beams.

- The ultimate deflection observed in sand coated GFRP reinforced beams is $34.8 \mathrm{~mm}$ and $39.62 \mathrm{~mm}$ in $0.73 \%$ and $1.04 \%$ reinforcement ratio respectively, which is higher than that observed in steel reinforced beams of $28.4 \mathrm{~mm}$. It shows $12 \%$ and $14 \%$ increase in deflection in sand coated GFRP reinforced beams when compared to steel reinforced beams.

- The ultimate load carrying capacity of grooved GFRP reinforced beam is $38 \mathrm{kN}$ and $56 \mathrm{kN}$ in $0.73 \%$ and $1.04 \%$ reinforcement ratio and the same in steel reinforced beams is $40 \mathrm{kN}$ in $0.73 \%$ reinforcement ratio. It shows $5 \%$ reduction and $25 \%$ increase in grooved GFRP reinforced beams compared to conventional steel reinforced beams.

- The ultimate deflection observed in grooved GFRP reinforced beams is $41.68 \mathrm{~mm}$ and $36.85 \mathrm{~mm}$ in $0.73 \%$ and $1.04 \%$ reinforcement ratio respectively, which is higher than that observed in steel reinforced beams of $28.4 \mathrm{~mm}$. It shows $14.5 \%$ and $13 \%$ increase in deflection in grooved GFRP reinforced beams when compared to steel reinforced beams.

- The number of cracks at ultimate load level is higher in sand coated GFRP beams when compared with grooved GFRP and steel reinforced beams.

- The grooved GFRP reinforced beams are found superior when compared to sand coated GFRP and conventional steel reinforced beams.

\section{REFERENCES}

1. Dinesh Kumar and Sathish Kumar (2018), Flexural Behaviour of Concrete Beams with GFRP Bars, International Research Journal of Engineering \& Technology, Vol.5(12), pp. 15951600.

2. Saraswathy $T$ and Dhanalakshmi M (2014), Investigation of Flexural Behaviour of RCC Beams Using GFRP Bars, International Journal of Scientific \&

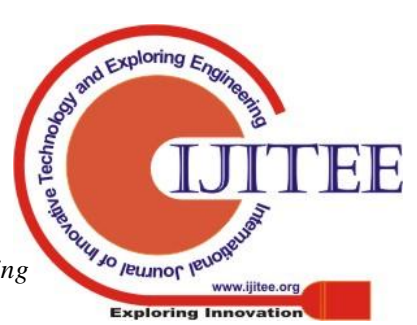


EngineeringResearch,Vol.5(1), pp. 333-338.

3. KhaledGalal and Munir Alp Enginsal (2011), Flexural Behaviour of GFRP Reinforced Concrete Masonry Beams, Journal of Composites for construction, Vol.5 (1), pp. 21-31.

4. Ascione L, Mancusi G and Spadea S (2010), Flexural Behaviour of concrete Beams Reinforced with GFRP Bars, Strain, An International journal of Experimental Mechanics, Vol.46, pp.460-469.

5. Code of Practice for, IS 10262: 2009, Indian Standard Methods of Concrete Mix Proportioning-Guidelines, BIS, New Delhi.

6. Code of Practice for, IS 456: 2000, Indian Standard Plain \& Reinforced Concrete, $B I S$, New Delhi.

7. Code of Practice for, IS 1608:2005, Metallic MaterialsTensile Testing at ambient Temperature, BIS, New Delhi.

8. ASTM-D 3916-84, Standard Test Methods for Tensile properties of Pultruded Glass-Fibre Reinforced Plastic.

9. Code of Practice for, IS 12269: 1987, Indian Standard Specification for 53 Grade Ordinary Portland Cement, BIS, New Delhi.

10. Code of Practice for, IS 2386 Part III : 1963,Indian Standard Method of Test for Aggregate for Concrete Mix Proportioning-Guidelines, BIS, New Delhi.

11. Code of Practice for, IS 9103: 1999, Indian Standard Specification for Concrete Admixtures, BIS, New Delhi.

12. Code of Practice for, IS 516: 1959, Methods of tests for strength of concrete, BIS, New Delhi.

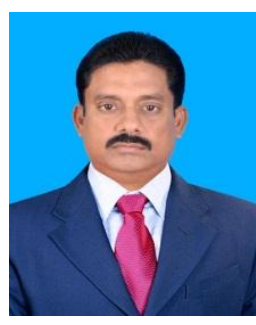

Murugan.R received B.E., M.E (Structures), Ph.D (Civil \&Structures) from Annamalai University. He served as Project Assistant at NIT-Tiruchirappalli in the year 1988-89, Surveyor at SURMAPS Ltd Bangalore in the year 1989-90, as Consulting Engineer and Contractor from 1991-2000. He joined as Lecturer in the Dept. of Civil and Structural Engg, Annamalai University in the year 2001 and presently working as Assistant Professor. His research area includes Non-Metallic (GFRP) Reinforcements for structural applications. He has published five research papers in referred International Journal and five papers in International conferences. His area of interest includes Solid Mechanics, Structural Mechanics, Concrete Technology and RCC Design. 